\title{
The relationship between successional vascular plant assemblages and associated microbial communities on coal mine spoil heaps
}

\author{
G. Woźniak ${ }^{1,4}$, A. Markowicz ${ }^{1}$, S. Borymski1 ${ }^{1}$, Z. Piotrowska-Seget ${ }^{1}$, D. Chmura ${ }^{2}$ \\ and L. Besenyei ${ }^{3}$ \\ ${ }^{1}$ Faculty of Biology and Environmental Protection, Katowice, Silesia, Poland \\ 2 Institute of Environmental Protection and Engineering, University of Bielsko-Biala, 2 Willowa Str, PL-43-309 \\ Bielsko-Biala, Poland \\ ${ }^{3}$ Faculty of Science and Technology, University of Wolverhampton, Wulfruna St., Wolverhampton, UK \\ ${ }_{4}^{4}$ Corresponding author.E-mail: wozniak@us.edu.pl
}

Keywords: Dominant species, Microbe-plant relation, Microbial communities, Post-industrial sites, Vegetation development.

\begin{abstract}
The aim of the study was to investigate the relationships between the vascular plant species and the associated soil microbial properties at various stages of vegetation development on unclaimed hard coal mine spoil heaps in Upper Silesia (south Poland). The spontaneous vegetation, soil chemistry as well as the activity and structure of microbial communities were recorded on this specific habitat. The colliery heaps were divided into four age classes and the plant species composition and cover abundance were recorded on established plots $(2 \mathrm{~m} \times 2 \mathrm{~m})$. The soil microbial activity under the vegetation patches was assessed using fluorescein diacetate hydrolytic activity (FDHA) and the soil microbial biomass and community composition were determined by phospholipid fatty acid (PLFA) biomarkers. Total microbial biomass in soils from the older vegetation plots was significantly higher than those in soils from the younger plots. In all studied samples, microbial communities consisted primarily of bacteria with the dominance of Gram negative bacteria over Gram positive and aerobic microorganisms were more dominant than anaerobic ones. Statistical analysis revealed a correlation between the type of vegetation and microbial community structure.
\end{abstract}

Abbreviations: Co-CA - Co-Correspondence Analysis, DCA-Detrended Correspondence Analysis, FDHA- , PCA-Principal Component Analysis, PLFA-, RDA - Redundancy Analysis

Nomenclature: for vascular plants Mirek et al. (2002).

\section{Introduction}

Coal mining activities cause extreme damage to ecosystems due to the production of large amounts of tailings that are deposited in vast heaps. These post-mining sites are specific environments usually characterized by an unfavorable granulometric structure consisting mostly of bedrock stone and gravel elements and very low amounts of organic matter, water and nutrients (Mendez and Maier 2008). In addition, acidic and anaerobic conditions frequently occur, which results in a presence of specific organisms, such as chemolithotrophic, acidophilic and thermophilic bacteria and plants (Moynahan et al. 2002, Patel and Behera 2011, Chmura and Molenda 2012). Nevertheless, enrichment in the existing microbial community and development of a diverse heterotrophic microbial community have been observed mostly as a result of vegetation development (Mendez et al. 2007, Helingerová et al. 2010, Patel and Behera 2011).

The soil microbial community is especially important in disturbed mine tailings systems because it enables the establishment of biogeochemical cycles, energy and nutrient transfer, as well as the formation of soil structure to facilitate the development of plant cover (Nannipieri et al. 2003, Mendez et al. 2007, Sinha et al. 2009). Plant root exudates facilitate growth and activity of soil microorganisms, that on the other hand promote plant growth by transforming soil organic matter, providing pathogen protection and producing growthpromoting substances (Moynahan et al. 2002, Rahmonov et al. 2011).

Relations between plants and micro-organisms, have strong structural and functional linkages in natural (Faliński 2003, Urbanová et al. 2011), semi-natural and in reclaimed soils (Liu et al. 2008, Zhang et al. 2011). It has been suggested that the feedback between soil microbial communities and plants determines both the plant vegetation development in subsequent successional stages as well as the activity and abundance of soil micro-organisms (Ehrenfeld et al. 2005; Schaaf et al., 2011). However, there are also many studies that show analysis based on the functional approach which present another aspect of diversity (Pokorny et al. 2005, Dzwonko and Loster 2007, Scherer-Lorenzen 2008, Woźniak et al. 2011).

It has been suggested that plant species composition has a strong selective influence on the soil microbial communities (Grayston et al. 2001). There are studies that show that plant 
species, enhance soil-development processes in waste sites and experimental conditions (Frouz et al. 2009, Chodak and Niklińska 2010). It has been found also, that different plant species produce various kind of organic matter in respect to the ratio of carbon sources of litter and/or root origin and also the amount of substances the particular tree species add to the soil influencing the soil $\mathrm{pH}$, or the content of macro-nutrients (Rahmomov 2009, Urbanová et al. 2011).

Almost all of these studies concern reclaimed sites of opencast brown coal mines. Data obtained about spontaneous, unreclaimed soil formation on post-mining sites are scarce, particular for the deep mining of hard coal. The origin of the waste material is important because these post-mining sites are specific environments and they differ (e.g., in terms of granulometric structure and $\mathrm{pH}$ ) depending on the industry (mining resources) they are connected with. Knowledge of spontaneous soil formation at post-mining sites, and the potential interplay between microbial function and composition alongside plant community development remains rudimentary.

Our long term study of spontaneous vegetation development on post-industrial sites and particularly on hard coal mine spoil heaps provided two sets of information. One was that the changes in the chemical and physical conditions of the site are not exclusively relevant to an explanation of the plant succession at hard coal spoil heaps (Rostański 2005, Woźniak 2010). The second was that the vegetation composition develops spontaneously on post-mining sites and differs from the majority of known described natural and semi-natural communities

The aim of the present study was to investigate the relationships between the plant species composition of the spontaneous vegetation and the associated microbial properties during the process of vegetation development on unreclaimed hard coal mine spoil heaps. We hypothesized that on post-hard coal mine heaps the microbial soil properties change along with the development of the spontaneous vegetation development. In detail, we formulated the following hypotheses

- The activity of soil microorganisms, determined by measuring fluorescein diacetate hydrolytic activity (FDHA), changes over time and that this is connected with vegetation development.

- Microbial communities expressed as PLFAs, both in terms of the categorical and quantitative aspects (biodiversity indices), are related to species composition and diversity of vegetation.

- Similar responses to soil parameters can be observed both in the cases of vegetation and microbial communities.

\section{Materials and methods}

\section{Study site}

The study was carried out on hard coal mine spoil heaps (Panewniki $\left(50^{\circ} 12^{\prime} 57^{\prime}\right.$ N, $\left.18^{\circ} 53^{\prime} 56^{\prime \prime} \mathrm{E}\right)$ Mysłowice

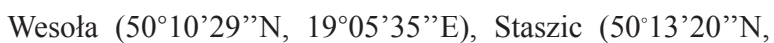

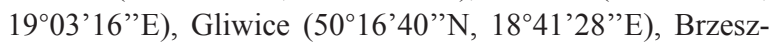
cze $\left(49^{\circ} 58^{\prime} 45^{\prime \prime} \mathrm{N}, \quad 1^{\circ} 11^{\prime} 26^{\prime \prime} \mathrm{E}\right), \quad$ Silesia $\left(49^{\circ} 56^{\prime} 32^{\prime \prime} \mathrm{N}\right.$, $19^{\circ} 01$ '11'E), Knurów (5009'58”N, 1941’55”E)) located in the Silesian Upland in southern Poland. This region is also called Upper Silesia, or Black Silesia, because of its long industrial tradition especially of coal mining. The climate is temperate with a mean annual precipitation of ca. $580 \mathrm{~mm}$ and a mean annual temperature of $7.6^{\circ} \mathrm{C}$. Coal mine spoil heaps provide habitats which consist of pure mineral substrate and can temporarily be extremely warm $\left(50^{\circ} \mathrm{C}\right.$ at about noon in summer) compared with the surroundings, but with no differences in precipitation (Woźniak 2010).

\section{Vegetation sampling}

The heaps were divided into four age classes (I - up to 10 yrs old, II - 11-30 yrs old, III - 31-60 yrs old, IV - more than $60 \mathrm{yrs}$ old). In each of the four age classes sampling plots (2 $\mathrm{m} \times 2 \mathrm{~m}$ ) were established (three dominant species in three replicates). A preliminary study enabled the preparation of a list of the most frequent dominant species for each age class of heap (Woźniak 2010). Dominant species in this study were defined as species whose cover within the patch was higher than the sum of cover of all other species in the patch. This list was the basis for choosing the patches for establishing the tested plots. In this way, we avoided the study of accidentally dominant species which could happen by using a totally random, or systematic, sampling design. In this sampling system the study focused on the most frequent dominant species in the vegetation development on each time series of different heaps. The sampling strategy influences the diversity measures. By sampling the most frequent vegetation type (dominant species) within each heap age class, it was possible to study the relationship between plant communities and the associated microbe communities found in vegetation patches in the harsh conditions of hard coal spoil heaps. The samples of the same dominant species were taken from separate heaps of the same age within similar geographical locations, so as not to change the abiotic characteristics. The plots were chosen by randomly stratifying the heaps for the dominant species on a heap of a particular age. The species composition and cover abundance were recorded within 36 plots (12 dominant species with three replicates of each dominant). The sampling scheme is presented in Table 1, while the species list of plants recorded on the studied plots, the value of the diversity $H$ 'index and statistics presenting the differences between the plots are included in Appendix 1. Species cover was assessed visually on a percentage scale with intervals of $10 \%$ except below $10 \%$, when cover levels of $1 \%$ and $5 \%$ were distinguished.

\section{Sampling and analyses of rhizosphere soil}

The rhizosphere soil samples were taken by shaking the soil from between the roots of individuals of dominant species. Composite soil samples consisting of 5 rhizosphere soil samples (in volume - core diameter $5 \mathrm{~cm}$, depth $15 \mathrm{~cm}$ ) were collected from the roots of dominant individual species grow- 
Table 1. The scheme of plots with the most frequent dominant species groups on the three sites investigated of hard coal mine spoil heaps of increasing age. Explanations: -sample taken from under the dominant species on one studied site; $\mathrm{a}$ - tree layer, $\mathrm{b}$ - shrub layer.

\begin{tabular}{|c|c|c|c|c|c|}
\hline \multirow{4}{*}{$\begin{array}{l}\text { Dominant species present in the } \\
\text { permanent plot }\end{array}$} & \multirow{4}{*}{ Abbreviation } & \multicolumn{4}{|c|}{ Heaps of different ages } \\
\hline & & Class age I & Class age II & Class age III & Class age IV \\
\hline & & Sites & Sites & Sites & Sites \\
\hline & & I, II, III & I, II, III & I, II, III & I, II, III \\
\hline Tussilago farfara & Tusfar & $\cdots$ & & & \\
\hline Poa compressa & Poacom & $\cdots$ & & & \\
\hline Chamaenerion palustris & Chapal & $\cdots$ & & & \\
\hline Calamagrostis epigejos & Calepi & & $\cdots$ & & \\
\hline Daucus carota & Daucar & & $\because$ & & \\
\hline Melilotus alba & Melalb & & $\because$ & & \\
\hline Populus tremula shrub & Poptre b & & & $\cdots$ & \\
\hline Pinus sylvestris shrub & Pinsyl b & & & $\cdots$ & \\
\hline Betula pendula shrub & Betpen $b$ & & & $\cdots$ & \\
\hline Betula pendula tree & Betpen a & & & & $\cdots$ \\
\hline Quercus robur tree & Querob a & & & & $\cdots$ \\
\hline Pinus sylvestris tree & Pinsyl a & & & & $\ldots$ \\
\hline
\end{tabular}

ing in the corners and in the middle of each of the 36 plots. Herbaceous plants were pulled out from the soil and the roots were shaken until the most of the adhering soil was removed. The remaining soil particles were removed by mechanical brushing and were considered as the rhizosphere. In the case of trees, their subsurface roots were excavated and fine roots with a tightly bound soil layer were carefully collected from five random points of their root system. To minimize variation between the rhizosphere soil samples all samples were collected on the same day. The soil samples from each plot were combined and sieved to the $2 \mathrm{~mm}$ fraction prior to subsampling for microbiological and soil chemical analyses. The soil subsample for chemical analysis was air-dried at $30^{\circ} \mathrm{C}$. Soil moisture contents were determined by gravimetric difference between $10 \mathrm{~g}$ wet and dry weights $\left(105^{\circ} \mathrm{C}\right.$ for 24 h) of soil samples. Soil pH was measured in distilled water (Dobrzański et al. 1987). Available potassium was analysed following Dobrzański et al. (1987). Available magnesium was analysed using the Schatschabel method (Dobrzański et al. 1987). Total phosphorus and total carbon were measured using the calorimetric and the Tiurin method, respectively. Organic carbon content analysis was carried out using the standard loss on ignition (LOI) method. The ammonium nitrogen $\mathrm{N}-\mathrm{NH}_{4}$ and nitrate nitrogen content were measured separately following the methods in Fotyma et al. (1998). Soil conductivity measurements $(\mathrm{C} 25)$ were also performed to assess the possible ionic content in the soil.

\section{Microbial analyses}

Fluorescein diacetate hydrolysis (FDHA) analysis. The measurement of total microbial activity using fluorescein diacetate hydrolytic activity (FDHA) was assessed using the method described by Adam and Duncan (2001). A unit of enzyme activity was defined as the $\mu \mathrm{g}$ of substrate hydrolyzed at $30^{\circ} \mathrm{C}$ by $1 \mathrm{~g}$ of dried soil. The enzymatic activity was determined in triplicate for each soil sample and the mean was taken.

Phospholipid fatty acid (PLFA) analysis. The composition of the soil microbial community was assessed using the phospholipid fatty acid method as described by Pennanen et al. (1996), with minor modifications. Briefly, the lipids after extraction with a Bligh-and-Dyer (chloroform, methanol, citrate buffer 1:2:0.8 v/v/v/), were fractionated into neutral, glycolipids and phospholipids on silicic acid columns and subjected to mild alkaline methanolysis. Phospholipid methyl esters were analyzed by gas-liquid chromatography (HewlettPackard 6890). Peak areas were estimated by adding methyl nonadecanoate fatty acid (19:0) as an internal standard. Total biomass was determined as the sum of all extracted PLFAs. Fatty acid nomenclature used was that described by Zelles (1999). The following PLFA biomarkers were assigned to major microbial groups: i15:0, a15:0, i16:0, i17:0, a17:0 for Gram-positive bacteria, 16:1w7, 18:1w7, cy17:0, cy19:0 for Gram-negative bacteria, 18:2w6,9 for fungi and 10Me17:0, 10Me18:0 for actinomycetes (Frostegård et al. 1993, 1996, Ehlers et al. 2010, Bird et al. 2011). Additionally, 15:0 and 17:0 fatty acid along with the above mentioned bacterial biomarkers were used for the calculation of total bacterial PLFA biomass. In addition, relative abundances of PLFAs were used to calculate the ratio of Gram-positive (GP) bacteria to Gram-negative (GN) bacteria, bacteria to fungi and total monosaturated fatty acids (MUFA) to total cyclopropyl fatty acids (CyFA) reflecting the distribution of aerobic and anaerobic micro-organism in the communities.

\section{Statistical analyses}

PLFA profiles were subjected to Principal Component Analysis (PCA). The structural diversity of the microbial community and the diversity of the plant vegetation were esti- 
mated using H' (Shannon-Wiener diversity index), S (species richness) and Pielou's evenness index. The Pearson productmoment correlation test was used to assess the relationship between the biodiversity indices of the microbial community and the vegetation data using Holm's correction for multiple tests. Univariate ANOVA, followed by Tukey test as posthoc, was used to examine any significant differences among groups of plots associated with particular dominant plant species.

In total 36 vegetation samples and their associated soil parameters were subjected to ordination analyses. Redundancy Analysis (RDA) was used to analyse the relationships between microbial community and soil properties. Canonical Correspondence Analysis (CCA) was used to analyse the relationship between plant species abundances and soil variables. The criterion of choice of different ordination methods in both communities was based on the difference in gradient length of the first axis. Prior to these analyses indirect ordination, Detrended Correspondence Analysis (DCA), was carried out to examine changes in the microbial community and plant data separately with increasing age of the heaps. For a short gradient $<2$ SD RDA was adopted, otherwise CCA was employed (CANOCO Software). In order to assess the relationship between the species composition of the vegetation and PLFA of the microbial community Co-Correspondence Analysis (Co-CA, Ter Braak and Schaffers 2004) was performed. The predictive Co-CA model with the SIMPLS algorithm and 999 permutations were used to calculate significant p-values for each ordination axis and were applied using the "cocorresp" package (Simpson 2009) of the R statistical software (www.r-project.org). To investigate the relationships between vegetation and microbial community structure, DCA scores of the first two axes from separate analyses were subjected to the Pearson correlation test.

\section{Results}

\section{Vegetation description}

The study was focused on the samples obtained from the most frequent vegetation type in each spoil heap age class. Herbs and grasses (Tussilago farfara, Poa compressa, Chamaenerion palustre) are the most frequent species on the youngest heaps. On the older heaps (age class II) the most frequent vegetation type consisted mainly of herbs and grasses (Daucus carota, Melilotus alba, and Calamagrostis epigejos). The most frequent vegetation on heaps aged up to 60 years was young trees in the shrub layer: Betula pendula, Populus tremula and Pinus sylvestris. The oldest heaps, those over 60 years old, were most frequently covered by patches dominated by tree stands of Betula pendula, Quercus robur and Pinus sylvestris. The number of the accompanying species in the vegetation on the youngest heaps varied from four, in patches dominated by Tussilago farfara, to 10 in the patches dominated by Poa compressa. In the vegetation patches studied belonging to the second age class the number of the accompanying species varied from 9, in patches dominated by Daucus carota, up to 14 in patches dominated by Melilotus alba. The most frequent vegetation on heaps aged up to 60 years varied in species number from 9 , in patches dominated by shrub Populus tremula, up to 15 in Pinus sylvestris shrub. While in vegetation studied on the oldest heaps the number of accompanying species varied from 12 in patches dominated by Betula pendula tree to 15 in patches dominated by Pinus sylvestris tree. The diversity indices $H^{\prime}$ and $S$ were generally found to increase significantly with time (Appendix 1).

\section{Soil characteristics}

The physical and chemical characteristics showed that there was little variation in $\mathrm{pH}$, potassium availability and phosphorus availability apart from in the plot of Betula pendula shrub (data not shown). The organic carbon content was the lowest in plots of Populus tremula shrub and Betula pendula shrub, while the $\mathrm{N}-\mathrm{NH}_{4}$ content was the highest in plots where Populus tremula shrub and Chamaenerion palustre were the dominants. The biggest variation was in the conductivity results (C25 - ionic content). A larger number of ions were present in the soil samples collected from the intermediate age heaps - in plots dominated by Calamagrostis epigejos and Daucus carota and the lowest ionic content was found in plots of the oldest heaps dominated by Pinus sylvestris tree, Quercus robur tree.

\section{Microbial activity and community composition}

Results of microbial activity measured as FDHA showed differences between the plots tested (data not shown). In plots of heaps of age classes I and II, the FDHA was very low compared with results for the plots from age classes III and IV, with the exception of samples from pine (Pinus sylvestris shrub - Ps b) and aspen (Populus tremula shrub Pt b). Between plots from age classes I and II, the highest FDH activity was observed under Poa compressa. Similar to the measurements of enzyme activity, the results of PLFA biomass showed significant differences within samples. The highest biomass of the microbes was recorded under trees, except pine (shrub and tree). Values for the bacteria to fungi ratio differed statistically between samples. The highest value was recorded for samples taken under Poa compressa (age class I), while the lowest value was for samples from trees growing on heaps of age class III. PCA and ANOVA analyses revealed a correlation of 18:2w6,9 fungal biomarker with dominants of this age class (data not shown). In general, the proportion of Gram-negative bacteria in microbial communities was high in all age classes. Significant changes in values of GP:GN ratio were observed between some successional stages. However, these results were more complex and depended on plant species, rather than age classes of coal mine heaps (data not shown).

\section{Relationship between microbial community, the vegetation and soil data}

There was a significant correlation between DCA scores for plots with floristic composition and scores of PLFA 
Table 2. Pearson's correlations between biodiversity indices of microbial community (PLFA) and vegetation. Adjusted p-values after Holm's correction are *: $\mathrm{p}<0.05$; **: $\mathrm{p}<0.01$; ns: non-significant. Abbreviations: H'- Shannon-Wiener index, $\mathrm{S}-$ species richness, E - evenness

\begin{tabular}{lrrc}
\hline & $H^{\prime}$ PLFA & S PLFA & E PLFA \\
\hline H'vegetation $^{\prime}$ & $0.58^{* *}$ & $0.52^{*}$ & $\mathrm{~ns}$ \\
S vegetation & $\mathrm{ns}$ & $\mathrm{ns}$ & $\mathrm{ns}$ \\
E vegetation & $\mathrm{ns}$ & $\mathrm{ns}$ & $\mathrm{ns}$ \\
\hline
\end{tabular}

Table 3. Summary of DCA and Co-CA ordinations of the microbial and plant communities

\begin{tabular}{llrrrr}
\hline \multirow{2}{*}{ Type of analysis } & \multirow{2}{*}{ Statistics } & \multicolumn{2}{c}{ Axis 1 } & \multicolumn{2}{c}{ Axis 2 } \\
\cline { 3 - 6 } & & PLFA & Vegetation & PLFA & Vegetation \\
\hline \multirow{3}{*}{ DCA } & Eigenvalues & 0.052 & 0.882 & 0.034 & 0.667 \\
& Lengths of gradient & 0.0886 & 5.423 & 0.714 & 4.12 \\
\multirow{2}{*}{ DCA axis correlation } & Cumulative \% variance & 26.2 & 10.6 & 43.3 & 18.7 \\
Co-CA & $\mathrm{P}$ & 0.64 & & 0.09 & \\
& $\mathrm{P}$ & $<0.0001$ & & $\mathrm{~ns}$ \\
\hline
\end{tabular}

Table 4. The $\mathrm{P}$ and $\mathrm{F}$ values of the Monte Carlo Permutation test for environmental factors (soil data) and explained variation (\%) of vegetation (CCA) and PLFA (RDA)

\begin{tabular}{lrrrrrr}
\hline Variable & \multicolumn{3}{c}{ PLFA } & \multicolumn{4}{c}{ Vegetation } \\
\cline { 2 - 7 } & \multicolumn{1}{c}{$\mathrm{P}$} & \multicolumn{1}{c}{$\mathrm{F}$} & \multicolumn{1}{c}{$\%$} & $\mathrm{P}$ & $\mathrm{F}$ & $\%$ \\
\hline Organic carbon & 0.001 & 17.84 & 60.8 & 0.001 & 2.47 & 42.7 \\
FDHA & 0.001 & 4.27 & 14.3 & 0.001 & 2.02 & 33.1 \\
$\mathrm{~N}-\mathrm{NH} 4$ & 0.039 & 2.10 & 7.1 & 0.044 & 1.44 & 24.5 \\
$\mathrm{Mg}$ & $\mathrm{ns}$ & 1.54 & - & $\mathrm{ns}$ & 1.19 & - \\
$\mathrm{P}$ & $\mathrm{ns}$ & 1.42 & - & $\mathrm{ns}$ & 1.02 & - \\
$\mathrm{C} 25$ & $\mathrm{~ns}$ & 1.31 & - & $\mathrm{ns}$ & 0.87 & - \\
$\mathrm{pH}$ & $\mathrm{ns}$ & 1.06 & - & $\mathrm{ns}$ & 1.16 & - \\
$\mathrm{K}$ & $\mathrm{ns}$ & 1.00 & - & $\mathrm{ns}$ & 1.22 & - \\
\hline
\end{tabular}
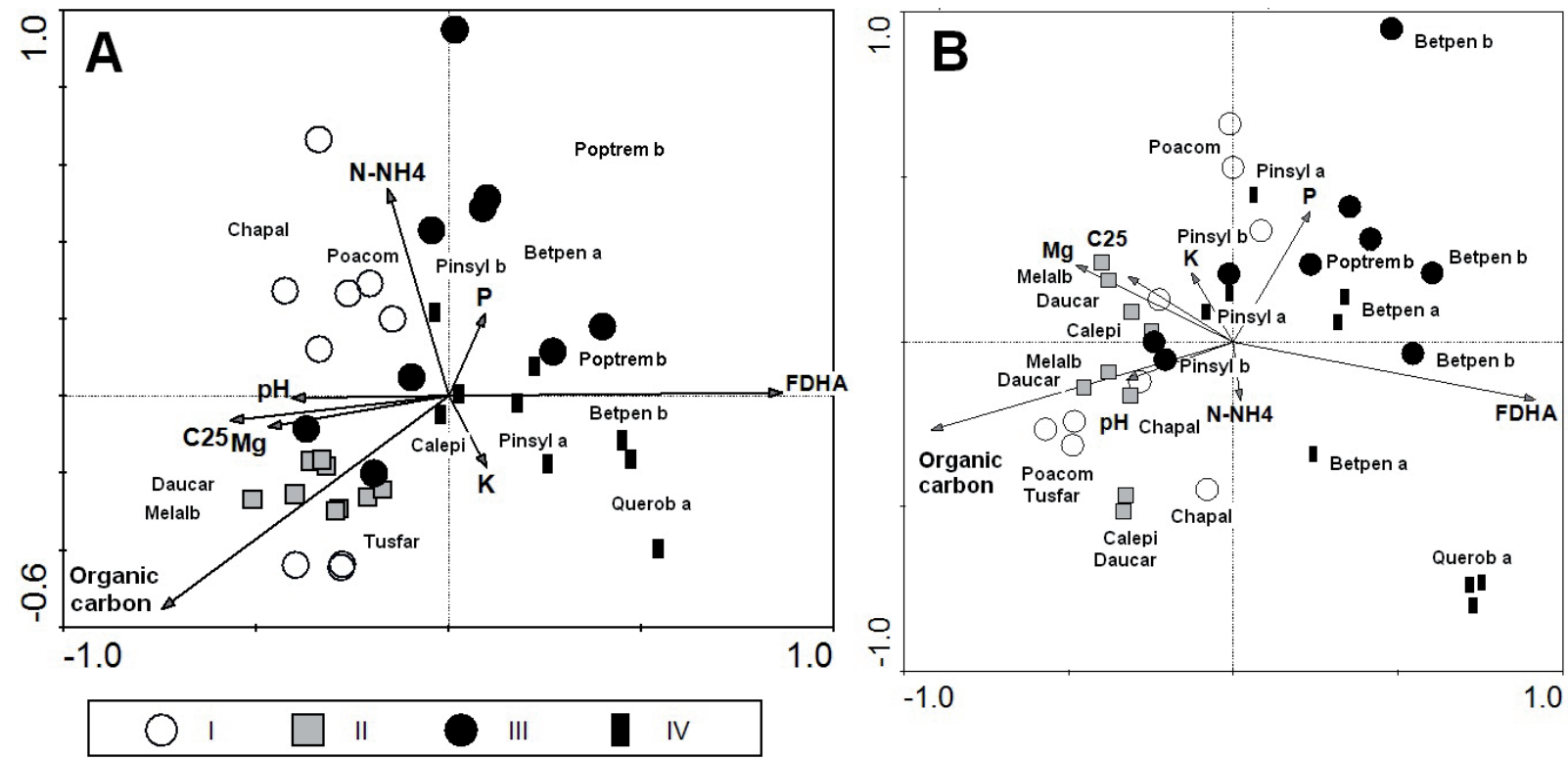

Figure 1. Ordination diagrams of CCA for vegetation (A) and RDA of microbial communities (B) for age classes I-IV. 
but only in the case of the first axis $(\mathrm{p}<0.0001)$ (Table 3$)$. Moreover, there were also significant positive correlations between the Shannon-Wiener diversity index, as well as between $H^{\prime}$ 'of the plant and microbial communities (Table 2). The Co-Correspondence analysis was used to describe the direct relationship between the composition of plant cover and the soil microbial community. When all the plant species were used as predictors using Co-CA analysis a Monte Carlo permutation test showed that the first two axes were significant (Table 3 last line). In both ordination analyses i.e., CCA and RDA, only organic carbon, FDHA and $\mathrm{N}-\mathrm{NH}_{4}$ ion concentration were significant explanatory variables, however, they differ in the percentage of explained variation in the community data (Table 4). In the CCA analysis of the vegetation data the first axis differentiates between plots of age classes I - II and those of III - IV. However, organic carbon and FDHA were correlated with the first axis of CCA and nitrate ammonium was correlated with the second axis (Fig. 1A). The plots of age class I were most associated with an increasing value of nitrate ammonium and the plots of age class II with organic carbon. In turn, results of FDHA showed that microbial activity in the plots of age classes III and IV are similar (Fig. 1A).

The RDA analysis of the PLFA composition revealed that organic carbon content and total microbial activity (FDHA) were discriminated along the first axis. The nitrate ammonium content was correlated with the second axis (Fig. 1B).

The first axis influences the differentiation of plots from age classes II and III along environmental variables. However, only organic carbon and FDHA significantly explained the variation in PLFA (Table 4). The plots of age classes I and II were more associated with organic carbon content, whereas plots of age classes III and IV were more associated with total microbial activity (Fig. 1 and Table 4).

\section{Discussion}

\section{Physico-chemical parameters of heap soil}

Many studies (Chodak et al. 2009, Chodak and Niklińska 2010, Mitchell et al. 2010) have shown that soil type, which embodies soil parent material, geology and chemistry, are key to explaining changes in vegetation development. However, on spontaneously developing sites, such as hard coal mine spoil heaps, weak correlations between abiotic soil characteristics and vegetation development have been observed (Woźniak 2010). The excavated material, which is deposited in heaps, can be assumed to be the pedogenic substrate, and its granulometric structure is an important feature.

In our study, stones and gravel were present even on the oldest heaps covered with woodland vegetation, it means that soil development was found to take much longer than vegetation development. The habitat was very poor and provide harsh conditions for plants and soil microorganisms. Due to the extreme variation in the soil within individual heaps, the chemical and physical properties do not give realistic information of the soil characteristics. This fact is reflected by the high values of the standard deviations of these parameters (data not shown). It is considered that the most important source of organic matter comes from leaf litter. Therefore the amount of organic matter increases over time with vegetation development (Zhang et al. 2011). In our study we found a very large amount $(24.51 \%)$ of organic C in the soil of the youngest heaps. This carbon also contains geogenic carbon, which originates from lignite particles from the tertiary strata. It should be underlined that geogenic carbon is not available for micro-organisms, thus, although there was a high total organic carbon content, the tested soils are poor and provide harsh conditions for micro-organisms and plant growth. A high contribution of coal material, which can reach the value of $30 \%$ of the total mass of material deposited, can be present in colliery coal mine spoil heaps has already been reported (Chakravorty and Kolada 1988). The presence of geogenic carbon in these kinds of heaps was also evidenced by Skarżyńska (1997).

\section{Vegetation}

Many field studies have revealed that apart from the theoretical constraints, living organisms colonise most of a colliery waste site abundantly and with high diversity (Rostański and Woźniak 2007, Tropek et al. 2008, Chmura et al. 2011). It is also possible to identify the most frequent plant communities which cover the largest area on spoil heaps of particular age (Woźniak 2010). On heaps the vegetation can be characterized as a mosaic of patches dominated by single species. (Cohn et al. 2001, Woźniak and Cohn 2007, Rahmonov 2009).

On natural and semi-natural sites vegetation development in time is often characterised by increasing values of diversity indices (Denslow 1980, and literature cited therein). Similarly in our study, the vegetation of the plots analysed had increasing Shannon-Wiener diversity indices values with increasing age of the heaps (Appendix 1). However, apart from the increasing diversity a tendency of increasing abundance of one species in patches was easy to record. Patches of vegetation dominated by the same species could occur in varied abiotic habitat conditions (Cohn et al. 2001). In natural soil microbial communities, composition of the vegetation and soil texture are related (Muller and Hoper 2004).

\section{Microbial and vegetation community relationships}

One of the most important soil parameters is microbial activity, since microbial communities are responsible for many ecological processes such as decomposition and nutrient cycling and pedogenesis (van der Heijden et al. 2008). The last function is essential for vegetation development, such as hard coal mine spoil heaps, where bare stones and gravel are predominant on the surface. The results of FDHA observed in soils from plots of age classes I and II suggested that the spoil material of hard coal mine heaps showed very low biological activity (in heaps below 30 years of age). These results are in agreement with the data obtained by Frouz et al. (2001) and Frouz and Nováková (2005) who studied microbial activity 
on reclaimed heaps after brown coal mining. Interestingly, the highest FDHA was obtained for vegetation patches dominated by deciduous species (Betula shrub, Quercus tree) and a pioneer grass (Poa compressa) which is confusing. An explanation may be provided by field observations. Poa compressa dominated vegetation patches occur exclusively on small site areas of very fine material mostly from dried puddles (personal observation). There is no agreement about the influence of trees on the soil parameters. Priha and Smolander (1997) reported no difference in organic carbon, total nitrogen and $\mathrm{pH}$ in mineral soils under 23-24 year old birch and pine forest stands in Finland. Chodak and Niklińska (2010) presume that a longer time is needed for trees to cause significant changes in soil biotic and abiotic properties.

The relationship between rhizosphere micro-organisms and plants is caused by the selection of bacterial taxa by plants (Huguet and Rudgers 2010) and these interactions are the most important for soil ecological studies (GarcíaPalacios et al. 2011). Plant composition influences below ground environmental conditions by driving changes in soil $\mathrm{pH}$, moisture, litter quality and rhizodeposition (Bezemer et al. 2006). However, changes in bacterial communities are also associated with soil properties (Williams et al. 2013).

In our study microbial communities in all soil samples were dominated by bacteria, with a dominance of Gramnegative bacteria over Gram-positive (data not shown). The dominance of Gram-negative bacteria in hard coal mine wastes was also reported by Kozdrój (2000). This is consistent with the suggestion that Gram-negative bacteria are more frequent under plants, preferably growing on plant labile $\mathrm{C}$ (Treonis et al. 2004, Koranda et al. 2011), and are also more tolerant of disturbance. Our results indicated that aerobic bacteria were dominant over anaerobic bacteria. However, in soil under Quercus robur dominated tree stands the relative abundance of aerobic bacteria was very low. The contribution of fungi varied significantly, which may indicate the presence of mycorrhizal fungi on some plants. Our studies showed that PLFA biomass increased along with the age of the studied heaps. The differences in PLFA biomass, as well as in FDHA, may also be due to changes in litter inputs since some authors suggest that there is a strong interaction between the composition of the litter and the active fraction of the microorganisms, which in turn affects the rate of decomposition (Elgersma and Ehrenfeld 2011). Trees, in comparison with herbaceous plants, have higher root length/mass and produce more litter, which is the reason for differences in FDHA and PLFA biomass between plants. The lower FDHA under pine, compared with other trees, may be due to the different quality of litter produced by these trees. The litter of Pinus sylvestris contains more recalcitrant waxes and lignins, and less tannins, and other easily degradable compounds, which may be used as a carbon source by micro-organisms when compared with of Betula species (Kiikkila et al. 2006, Adamczyk et al. 2008, Chodak and Niklińska 2010).

In our study, Tussilago farfara was an important pioneer plant species. It was one of three species which was most frequently recorded as a dominant on the youngest unreclaimed coal mine heaps. Elhottova et al. (2009) used this species in their experimental ecosystem, for colonizing the mine spoil and characterizing the rhizosphere effect on the spoil microbial community. They found a significantly higher activity of microbial communities, higher growth of culturable microorganisms and greater metabolic potential, enriched by the spoil under the root influence of T. farfara. This plant and its rhizosphere microflora could significantly improve the spontaneous vegetation development on post-mining colliery sites (Elhottova et al. 2009). The ordination analyses reveal (Fig. $1 \mathrm{~A}$ and $\mathrm{B}$, Table 4) that organic carbon was the major factor influencing the variability of microbial communities, which may be explained by the rhizosphere effect.

Interactions between soil microbes and surface vegetation have become an important issue for ecological study (De Deyn et al. 2011). Correlation between the vegetation diversity and the changes in functional diversity of soil microbial communities during the restoration process of the degraded grassland were studied by García-Palacios et al. (2011).

Our results show a relation between species diversity of vegetation $\left(H^{\prime}\right)$ and microbial diversity in terms both of the value of the Shannon-Wiener index as well as PLFAs richness which was revealed by co-correspondence analysis. This effect may result from the fact that increased PLFA diversity may cause the increase of vegetation diversity, or higher microbial diversity may result from the vegetation development. It is also possible that plant and microbial both communities respond similarly to the same abiotic factors. The positive feedback in ecological systems seems to be a general rule as they were already well recognized between flowering plants and various functional groups of insects: herbivores, parasites and predators, pollinators, flower visitors (Hatfield and LeBuhn 2007, Chmura et al. 2013).

Van der Heijden et al. (1998) found a positive relationship between fungal species richness and plant species diversity. So, it can be expected that diversity of fungal PLFAs will correspond to plant species richness. It has already been demonstrated that abundance of PLFAs is related to plant species richness and vegetation composition (De Deyn et al. 2011). Results of our study confirmed that environmental factors influence on vegetation and microbial communities and there is a feedback between plant productivity and changes in soil parameters due to leaf litter, decomposition of plant biomass and interaction with soil biota. The most important soil parameter turned out to be organic carbon which explained the highest variation in percentages of both vegetation (42\%) and PLFAs (60\%) (Table 4). The high percentage of vegetation variation explained by FDHA may be caused by the fact that hydrolytic enzymes are important for providing available forms of nutrients. The higher impact of N-NH4 for plants resulted from the fact that this form of nitrogen is crucial for plant growth.

The differences in microbial composition and activity are closely related to root exudates and plant debris, which differ from one plant species to another (Warembourg et al. 2003, Garcia et al. 2005). In coal mine heaps soil, the type of vegetation is of high importance for the microbial properties and vice versa. Mitchell et al. (2007), studying the correlation 
between vegetation composition and soil microbial community on moorland, stated that plant species composition may be a useful tool for predicting microbial community structure to the same extent as chemical analysis. Our results support this theory and indicate that it is also true along successional gradients on man-made habitats. In addition, the activity and structure of microbial populations strongly influence plant development.

\section{Conclusion}

The analyses used in our study revealed a strong correlation between vegetation and microbial community structure on hard coal spoil heaps. Our results supported the hypothesis that (1) the activity of soil micro-organisms, determined by measuring fluorescein diacetate hydrolytic activity (FDHA), depends on the stage of vegetation development, (2) PLFA profiles correspond to species composition and diversity of vegetation and (3) similar responses to soil parameters can be observed both in the case of vegetation and in microbial communities.

Acknowledgements: The study was supported by grant no. N305 046336 and partially supported by grant no. N304 092434 from the Polish Ministry of Science and Higher Education.

\section{References}

Adam, G. and H. Duncan. 2001. Development of a sensitive and rapid method for the measurement of total microbial activity using fluorescein diacetate (FDA) in a range of soils. Soil Biol. Biochem. 33: 943-951.

Adamczyk, B., V. Kitunen and A. Smolander 2008. Protein precipitation by tannins in soil organic horizon and vegetation in relation to tree species. Biol. Fertil. Soils. 45: 55-64.

Bezemer, T.M., C.S. Lawson, K. Hedlund, A.R. Edwards, A.J. Brook, J.M. Igual, S.R. Mortimer and W.H. van der Putten. 2006. Plant species and functional group effects on abiotic and microbial soil properties and plant-soil feedback responses in two grasslands. J. Ecol. 94: 893-904.

Bird, J.A., D.J. Herman, and M.K. Firestone. 2011 Rhizosphere priming of soil organic matter by bacterial groups in a grassland soil. Soil Biol. Biochem. 43:718-725.

Chakravorty, R.N. and R.J. Kolada. 1988. Prevention and control of spontaneous combustion in coal mines. Mining Engineering 40: 952-956.

Chmura, D., P. Adamski and Z. Denisiuk. 2013. How do plant communities and flower visitors relate? A case study of semi-natural xerothermic grasslands. Acta Soc Bot Pol. 82(2): 99-105.

Chmura, D. and T. Molenda. 2012. Influence of thermally polluted water on the growth of helophytes in the vicinity of a colliery waste. Water, Air and Soil Pollution 223(9): 5877-5884.

Chmura D., T. Molenda, A. Błońska and G. Woźniak. 2011. Sites of leachate inflows on coalmine heaps as refuges of rare mountainous species. Polish Journal of Environmental Studies 20(3): 551-557.
Chodak, M. and M. Niklińska. 2010. Effect of texture and tree species on microbial properties of mine soils. Appl. Soil Ecol. 46: 268-275.

Chodak, M., M. Pietrzykowski and M. Niklińska. 2009. Development of microbial properties in a chronosequence of sandy mine soils. Appl Soil Ecol. 41: 259-268.

Cohn, E.V., A. Rostański, B. Tokarska-Guzik, I.C. Trueman and G. Woźniak. 2001. The flora and vegetation of an old solvay process tip in Jaworzno (Upper Silesia, Poland). Acta Soc Bot Pol. 70(1): 47-60.

De Deyn, G.B., H. Quirk and R.D. Bardgett. 2011. Plant species richness, identity and productivity differentially influence key groups of microbes in grassland soils of contrasting fertility. Biology Letters 7(1): 75-78.

Denslow, J. S. 1980. Patterns of plant species diversity during succession under different disturbance regimes. Oecologia 46(1): $18-21$.

Dobrzański, B., S. Udziak, Z. Klimowicz and J. Melke. 1987. Badanie gleb $w$ laboratorium $i$ w polu. Przewodnik do ćwiczeń z gleboznawstwa dla studentów biologii i geografii. Wyd. Uniwersytetu Marii Curie-Skłodowskiej, Lublin, pp. 329.

Dzwonko, Z., Loster, S. 2007. A functional analysis of vegetation dynamics in abandoned and restored limestone grasslands $J$. Veg. Sci. 18 (2): 203-212.

Ehlers, K., L.R. Bakken, Å. Frostegård, E. Frossard, and E.K. Bünemann. 2010. Phosphorus limitation in a Ferralsol: Impact on microbial activity and cell internal $\mathrm{P}$ pools. Soil Biol. Biochem. 42: 558-566.

Ehrenfeld, J.G., B. Ravit and K. Elgersma. 2005. Feedback in the plant-soil system. Annu. Rev. Environ. Resour. 30: 75-115.

Elgersma, K.J., and J.G. Ehrenfeld. 2011. Linear and non-linear impacts of a non-native plant invasion on soil microbial community structure and function. Biol. Invasions 13: 757-768.

Elhottova, D., V. Kristufek, S. Maly and J. Frouz. 2009. Rhizosphere effect of colonizer plant species on the development of soil microbial community during primary succession on post mining sites. Commun. Soil Sci. Plan. 40: 758-770.

Faliński, J. 2003. Long term studies on vegetation dynamics: some notes on concepts, fundamentals and conditions. Community Ecol. 4(1): 107-113.

Fotyma, E, G. Wilkos and C. Pietruch. 1998. Test glebowy azotu mineralnego możliwości praktycznego wykorzystania. IUNG, Puławy. pp. 48.

Frostegård Å., and E. Bååth. 1996. The use of phospholipid fatty acid analysis to estimate bacterial and fungal biomass in soil. Biol. Fertil. Soil. 22: 59-65.

Frostegård, Å., A. Tunlid and E. Bååth. 1993. Phospholipid fatty acid composition, biomass, and activity of microbial communities from two soil types experimentally exposed to different heavy metals. Appl. Environ. Microbiol. 59(11): 3605-3617.

Frouz, J., B. Keplin, V. Pižl, K. Tajovský, J. Starý, J.A. Lukešová, A. Nováková, V. Balík, L. Háněl, J. Materna, C. Düker, J. Chalupský, J. Rusek, and T. Heinkele. 2001. Soil biota and upper soil layers development in two contrasting post-mining chronosequences. Ecol. Eng. 17: 275-284.

Frouz, J. and A. Nováková. 2005. Development of soil microbial properties in top soil layer during spontaneous succession in heaps after brown coal mining in relation to soil microstructure development. Geoderma 129: 54-64.

Frouz, J., V. Pil, E. Cienciala and J. Kalcík. 2009. Carbon storage in post-mining forest soil, the role of tree biomass and soil bioturbation. Biogeochemistry 94: 111-121. 
Garcia, C., A. Roldan and T. Hernandez. 2005. Ability of different plant species to promote microbiological processes in semiarid soil. Geoderma 124: 193-202.

García-Palacios, P., M. Bowker, S. Chapman, F. Maestre and S. Soliveres. 2011. Early-successional vegetation changes after roadside prairie restoration modify processes related with soil functioning by changing microbial functional diversity. Soil Biology and Biochemistry 43(6): 1245-1253.

Grayston, S.J., G.S. Griffith, J.L. Mawdsley, C.D. Campbell and R.D. Bardgett. 2001. Accounting for variability in soil microbial communities of temperate upland grassland ecosystems. Soil Biol. Biochem. 33: 533-551.

Hatfield, R.G. and G. LeBuhn. 2007. Patch and landscape factors shape community assemblage of bumble bees, Bombus spp. (Hymenoptera: Apidae), in montane Meadows. Biol. Conserv. 139: $150-158$.

Helingerová M., Frouz J. and H. Šantrůčková. 2010. Microbial activity in reclaimed and unreclaimed post-mining sites near Sokolov (Czech Republic). Ecol. Eng. 36: 768-776.

Huguet, V. and J.A. Rudgers. 2010. Covariation of soil bacterial composition with plant rarity. Appl. Environ. Microbiol. 76: 76657667.

Kiikkilä, O., V. Kitunen and A. Smolander. 2006. Dissolved soil organic matter from surface organic horizons under birch and conifers: degradation in relation to chemical characteristics. Soil Biol. Biochem. 38: 737-746.

Koranda, M., J. Schnecker, C. Kaiser, L. Fuchslueger, B. Kitzler, C.F. Stange, A. Sessitsch, S. Zechmeister-Boltenstern and A. Richter. 2011. Microbial processes and community composition in the rhizosphere of European beech - The influence of plant $\mathrm{C}$ exudates. Soil Biol. Biochem. 43: 551-558.

Kozdrój J. 2000. Microflora of technogeous wastes characterised by fatty acid profiling. Microb. Res. 155: 149-156

Liu, Z., G. Liu, B. Fu and X. Zheng. 2008. Relationship between plan species diversity and soil microbial functional diversity along a longitudinal gradient in temperate grasslands of Hulunbeir, Inner Mongolia, China. Ecol. Res. 23: 511-518.

Mendez M.O. and R.M. Maier. 2008. Phytostabilization of mine tailings in arid and semiarid environments - an engineering remediation technology. Environ. Health Perspect. 116(3): 278-283.

Mendez M.O. Glenn E.P. and R.M. Meier. 2007. Phytostabilization potential of quailbush for mine tailings: growth, metal accumulation and microbial community changes. J. Environ. Qual. 36: $245-253$.

Mirek, Z., H. Piękoś-Mirkowa, A. Zając and M. Zając. 2002 Flowering plants and pteridophytes of Poland a checklist. W. Szafer Institute of Botany PAN. Kraków. pp. 442.

Mitchell, R.J., A.J. Hester, C.D. Campbell, S.J. Chapman, C.M. Cameron, R.L. Hewison and J.M. Potts. 2010. Is vegetation composition or soil chemistry the best predictor of the soil microbial community? Plant Soil. 333: 417-430.

Mitchell, R.J., C.D. Campbell, S.J. Chapman, G.H. Osler, A.J Vanbergen, L.R. Ross, C.M. Cameron and L. Cole 2007. The cascading effects of birch on heather moorland: a test for the top-down control of an ecosystem engineer. J. Ecol. 95: 540-554.

Moynahan O.S., C.A. Zabinski and J.E. Gannon. 2002. Microbial community structure and carbon-utilization diversity in a mine tailings revegetation study. Restor. Ecol. 10: 77-87.

Muller, T. and H. Hoper. 2004. Soil organic matter turnover as a function of the soil clay content: consequences for model applications. Soil Biol. Biochem. 36: 877-888.
Nannipieri, P., J. Ascher, M.T. Ceccherini, L. Landi, G. Pietramellara and G. Renella. 2003. Microbial diversity and soil function. Eur. J. Soil Sci. 54: 655-70.

Patel A.K. and N. Behera. 2011. Genetic diversity of coal mine spoil by metagenomes using random amplified polymorphic DNA (RAPD) marker. Ind. J. Biotechnol. 10: 90-96.

Pennanen, T., A. Frostegård, H. Fritze and E. Bååth. 1996. Phospolipid fatty acid composition and heavy metal tolerance of soil microbial communities along two heavy metal-polluted gradients in coniferous forests. Appl. Environ. Microbiol. 62: 420-428.

Pokorny, M., R. Sheley, C. Zabinski, R. Engel, T. Svejcar and J. Borkowski. 2005. Plant functional group diversity as a mechanism for invasion resistance. Restoration Ecol. 13: 448-459.

Priha, O. and A. Smolander. 1997. Microbial biomass and activity in soil and litter under Pinus sylvestris, Picea abies and Betula pendula at originally similar field afforestation sites. Biol. Fertil. Soils. 24: 45-51.

Rahmonov, O. 2009. The chemical composition of plant liter of black locust (Robinia pseudoacacia L.) and its ecological role in sandy ecosystems. Acta Ecologica Sinica 29(4): 237-243.

Rahmonov, O., M.A. Rzętała, M. Rahmonov, E. Kozyreva, A. Jagus and M., Rzętała. 2011. The formation of soil chemistry and the development of fertility islands under plant canopies in sandy areas. Research Journal of Chemistry and Environment 15(2): 823-829.

Rostański, A. 2005. Specific features of the flora of colliery spoil heaps in selected European regions. Polish Botanical Studies 19: 97-103.

Rostański, A. and G. Woźniak. 2007. Grasses (Poacae) on post-industrial waste sites in course of spontaneous succesion. Fragmenta Floristica et Geobotanica 9: 31-42.

Schaaf, W., O. Bens, A. Fischer, H.H. Gerke, W. Gerwin, U. Grünewald, H.M. Holländer , I. Kögel-Knabner, M. Mutz, M. Schloter, R. Schulin, M. Veste, S. Winter and R.F. Hüttl. 2011. Patterns and processes of initial terrestrial-ecosystem development. J. Plant Nutr. Soil Sci. 174: 229-239.

Scherer-Lorenzen, M. 2008. Functional diversity affects decomposition processes in experimental grasslands. Functional Ecol. 22: 547-555.

Simpson, G.L. 2009. cocorresp: Co-correspondence analysis ordination methods. (R package version 0.1-9). (http://cran.r-project. org/package=analogue).

Sinha, S., R.E. Masto, L.C. Ram, V.A .Selvi, N.K. Srivastava, R.C. Tripathi and J. George. 2009. Rhizosphere soil microbial index of tree species in a coal mining ecosystem. Soil Biol Biochem. 41: $1824-1832$

Skarżyńska, K.M. 1997. Odpady powęglowe i ich zastosowanie w inżynierii lądowej $i$ wodnej. Wydawnictwo Akademii Rolniczej. Krakow. pp. 110.

ter Braak, C.J. and A.P. Schaffers. 2004. Co-correspondence analysis: a new ordination method to relate two community compositions. Ecology 85: 834-846

Treonis, A.M., N.J. Ostle, A.W. Stott, R. Primrose, S.J. Grayston and P. Ineson. 2004. Identification of groups of metabolically-active rhizosphere microorganisms by stable isotope probing of PLFAs. Soil Biol. Biochem. 36: 533-537.

Tropek, R., L. Spitzer and M. Konvicka. 2008. Two groups of epigeic arthropods differ in colonising of piedmont quarries: the necessity of multi-taxa and life-history traits approaches in the monitoring studies. Community Ecol. 9: 177-184.

Urbanová, M., J. Kopecký, V. Valásková, M. Ságová-Marecková, D. Elhottová, M. Kyselková, Y. Moënne-Loccoz and P. Baldrian. 
2011. Development of bacterial community during spontaneous succession on spoil heaps after brown coal mining. FEMS Microbiology Ecology 78, 59-69.

van der Heijden, M., J. Klironomos, M. Ursic, P. Moutoglis, R. Streitwolf-Engel, T. Boller, A. Wiemken and I. Sanders. 1998. Mycorrhizal fungal diversity determines plant biodiversity, ecosystem variability and productivity. Nature 396: 69-72.

van der Heijden, M.G., R.D. Bardgett and N.M. van Straalen. 2008. The unseen majority: soil microbes as drivers of plant diversity and productivity in terrestrial ecosystems. Ecol Lett. 11: 296310.

Warembourg, F.R., C. Roumet and F. Lafont. 2003. Differences in rhizosphere carbon partitioning among plant species of different families. Plant Soil. 256: 347-357.

Williams, M.A., K. Jangid, S.G. Shanmugam and W.B. Whitman. 2013. Bacterial communities in soil mimic patterns of vegetative succession and ecosystem climax but are resilient to change between seasons. Soil Biol. Biochem. 57:749-757.

Woźniak, G. 2010. Diversity of vegetation on coal-mine heaps of the Upper Silesia (Poland). W. Szafer Institute of Botany, Polish Academy of Sciences. Krakow.

Woźniak, G. and E.V. Cohn. 2007. Monitoring of spontaneous vegetation dynamics on post coal mining waste sites in Upper Silesia,
Poland. In: R.W. Sarsby and A. Felton (eds.), Geotechnical and Environmental Aspects of Waste Disposal Sites. Taylor and Francis Group. London. pp. 289-294.

Woźniak, G., D. Chmura, A. Błońska, E. Sierka and B. TokarskaGuzik. 2011. Applicability of the concept of functional groups for analysis of spatiotemporal vegetation changes on manmade habitats. Polish Journal of Environmental Studies 20(3): 623631.

Zelles, L. 1999. Fatty acid patterns of phospholipids and lipopolysaccharides in the characterization of microbial communities in soil: a review. Biol. Fertil. Soils 29: 111-129.

Zhang, Ch, G. Liu, S. Xue and Z. Song. 2011. Rhizosphere soil microbial activity under different vegetation types on the Loess Plateau, China. Geoderma 161: 115-125.

Received October 12, 2013

Revised February 23, May 14, 2014 Accepted July 17, 2014

\section{Appendix 1}

List of plants, the site parameters recorded on the plots, the value of the diversity index $\mathrm{H}^{\prime}$ and species richness $\mathrm{S}$. The file may be downloaded from www.akademiai.com. 